\title{
Diversity of poverty in the chosen European Union countries within the period 2006-2014 ${ }^{* 1}$
}

\author{
Anna Iwacewicz-Orłowska ${ }^{2}$
}

\begin{abstract}
The main purpose of the study is to analyse the poverty level changes in the chosen European Union countries in years 2006-2014. The poverty and inequality issue gained a global dimension. Income inequality in most countries is significantly higher than thirty years ago. Analysis was based on the statistical data source The European Union Statistics on Income and Living Conditions (EU-SILC) for four countries: the Czech Republic, Hungary, Poland and Slovakia and the method of the data analysis has been used. The Gini coefficient and a people at-risk-ofpoverty or social exclusion indexes were used for this analysis. Differences in the level of poverty depends on the following determinants: the age, the territorial location, the size of the town and the most frequent activity status. Results of research shows that main groups exposed to the poverty in the chosen EU countries are above all unemployed persons and their families, young persons, children and inhabitants of towns, suburbs and rural areas. Inhabitants from outlying districts, far from the capital city of the country are threatened with the higher level of poverty in each analysed country. The results of the research prove that the poverty at different levels afflict different social groups.
\end{abstract}

Key words: at-risk-of-poverty rate, Gini coefficient, inequality, poverty

JEL classification: D63, I31

\footnotetext{
* Received: 18-05-2016; accepted: 09-12-2016

1 The research leading to these results has received support under the European Commission's $7^{\text {th }}$ Framework Programme (FP7/2013-2017) under grant agreement n`312691, InGRID - Inclusive Growth Research Infrastructure Diffusion. This work is supported by statutory research for University of Finance and Management in Białystok, Economic Department.

2 PhD, University of Finance and Management in Biatystok, Poland, ul. Ciepła 40, 15-472 Biatystok, Poland. Scientific affiliation: economics. Phone: +048 692464 884. E-mail: anna. orlowska@wsfiz.edu.pl.
} 


\section{Introduction}

The literature points that as the world becomes more integrated, the global dimension of poverty and inequality is likely to become increasingly relevant. This is for at least two reasons: the much - increased movement of factors of production across borders, and the greater influence of other people's (foreigners') standard of living and way of life on one's perceived income position and aspirations (Milanović, 2013: 198). The others shows that the recent rise of poverty is due not only to technology and globalisation but reflects the institutions and policies adopted in the labour and capital markets (Atkinson, 2013:10).

A high diversity of poverty and income inequalities results first of all from lack of employment security. The high level of unemployment and decreasing incomes are the main uncertainty factors. Other determinants could be lack of financial stability, lack of permanent employment, lack of social calmness. Currently all over the world, we can observe increased uncertainty and anxiety due to unemployment, worse remuneration, and decreasing labour market flexibility. The above factors confirm that we are dealing with a low level of social security, which is an arrangement of relations which should be corrected (Kołodko, 2008; Leszczyński, 2009; Leszczyński, 2011: 185; Żukrowska, 2006).

The hypothesis of this research is differences in the level of poverty depends on the following determinants: the age, the territorial location, the size of the town and the most frequent activity status.

The paper is organized as follows. The next section presents overall trends in income inequality, explain the Gini index and at-risk-of-poverty rate. Section three describes the methodology and method of analysis. Section four presents the data description. Section five presents results and the last section concludes the research.

\section{Literature review}

The current paper is taking up the problem of the inequality among four countries that belongs to the Visegrad Group. The Czech Republic, Hungary, Poland and Slovakia have always been part of a single civilization and also now those countries work together in a number of fields of common interest within the all-European integration. Existing studies treated these countries homogeneously not including the analyses concerning their internal diversity in the matter of social inequalities. Therefore it seems that the analysis of the inequality level in described countries is an important issue.

The recent research shows that poverty and inequalities issue gained a global dimension. Income inequality in most countries is significantly higher than 
thirty years ago. Stiglitz (2012: 24) points that the crisis 2007-2008 made these inequalities worse in innumerable ways, beyond the higher unemployment, lost homes, stagnating wages. The wealthy had more to lose in stock market values, but those recovered reasonably well and relatively fast. Not only is the middle class shrinking in size - with more people in poverty — but the incomes at the top have pulled away from those in the middle (Stiglitz, 2015: 427).

Copeland and Daly (2014) prove that the target of Europan Union social policy to reduce poverty and social exclusion by 20 million is ungovernable. They show that it melds different approaches to poverty and social exclusion and because of the leeway to Member States to adopt an approach of their own choice. And the target is ungoverned because of low political priority and uncertainty around its legal status, as well as ambiguity over how it fits into the Europe 2020 governance process.

Cingano (2014: 6) noticed that the rise in overall income inequality is not (only) about surgoing top income shares: often, incomes at the bottom grew much slower during the prosperous years and fell during downturns, putting relative (and in some countries, absolute) income poverty on the radar of policy concerns.

Bowles (2012) argues that, quite apart from its moral dimension, such inequality is economically inefficient. It leads to excessive expenditure on the enforcement of property rights and on crime prevention. It also reduces labour productivity. Over the past forty years, the gap between rich and poor has widened dramatically in many industrialised countries, and what Americans call the 'middle class' has shrunk.

The literature points methods of measurement of the poverty. Betti et al. (2012: 144) describe special technical procedures involved in this process. These include consolidation of measures defined with reference to different poverty line thresholds in the income distribution, cumulation of data or measures over multiple survey waves and use of small area estimation methods. As the result they point that relative indicators of inequality are found to be highly correlated with diverse aspects of the level of well-being of a society. Furthermore, in more unequal societies, it is not only those at the bottom but also practically the whole population that suffers from lower levels of well-being.

The most often used in international comparisons of poverty is the Gini coefficient, which describes income disproportions. The Gini Index is an inequality measure that is mostly associated with the descriptive approach to inequality measurement. The Gini Index is a complex inequality measure and, as with many inequality measures, it is a synthetic index. Therefore, its characteristic is that of giving summary information on the income distribution and that of not giving any information about the characteristics of the income distribution, like location and shape (Bellù and Liberati, 2006: 6). The Gini rate fluctuates from 0 to $1(0 \%$ to 
$100 \%$ ). The coefficient value is equal to 0 when all members of the examined group have equal incomes. Value 1 means that all the income goes to 1 member of this group. The value of the indicator is higher if the degree of income concentration is greater resulting in greater income disparity.

The observing tendency in the Gini coefficient is alarming. In spite of growing disproportions in income distribution between people in individual countries, this disproportion is generally decreasing between countries. Poorer countries are slowly equalizing the standard of living compared with rich countries (Förster and Pearson, 2002: 9). We can state that according to the Gini coefficient Greece and Finland recorded the biggest decrease in income inequality. Finland's rank, as an example of a Scandinavian welfare state country, is not surprising, but Greece yes. The change in the Gini coefficient was an effect of the rise in incomes amongst the poorest part of society. Unfortunately, this had disadvantageous results for Greece's economic situation in the first decades of the $21^{\text {st }}$ century. Next, the biggest increase of the Gini coefficient occurred in Great Britain, Italy, and Turkey.

European Union divided common indicators of social protection and social inclusion into two groups: primary indicators and secondary indicators. In both of them first place has at-risk-of-poverty rate (Haase and Foley, 2009).

The 'at-risk-of-poverty' rate is the most widely recognised indicator of income poverty. Its principal advantage is that it is relatively straightforward to define and (given appropriate data) to calculate. National at-risk-of-poverty rates play a key role in monitoring EU2020 objectives relating to combating poverty. Regional patterns of poverty have the potential to deepen our understanding of processes of impoverishment and differentiation, and how they can be more effectively addressed by policy. Estimating regional poverty rates, and especially producing a European map, is a challenging task, given current data resources. (Copus et al., 2015: 742). The at-risk-of-poverty rate is being defined as the percentage of persons in households, in which level of expenditure (including the value of articles received free of charge and the value of the natural consumption also) was lower than accepted poverties threshold (Ubóstwo ekonomiczne w Polsce w 2014, 2015: 7).

At-risk-of-poverty threshold is calculated using equivalised household income. Accepted poverties thresholds are:

- The basic necessities level, accepted as abject poverty threshold. It is taking into account only these needs, of which the consumption cannot be postponed in the time, and the consumption lower than this level causes the biological emaciation.

- Statutory poverties threshold (threshold of social intervention), determined as the amount which according to the law is authorizing to apply for granting cash benefits from the institution of the welfare. 
- Relative poverties threshold, determined as the $50 \%$ of average expenses of the whole households (based on results of the households budgets calculation).

- The poverty in the different level concern individual social groups. Basic factors that determined financial situation of the individuals or families are:

- their situation on the labour market. Above all unemployed persons and families of unemployed persons are threatened with the poverty. The larger number of the unemployed people in the household is considerably increasing the risk of extreme poverty.

- the level of the poverty is clearly diversified depending on socio-economic groups, determined based on a predominating source of revenue.

- the education is one of the most important factor diversifying poverty. Fundamentally, the higher education is, the smaller the risk of living below the basic necessities.

- the reach of the poverty depends on the age;

- the disabled person in the family is favouring the poverty;

- the place of living (urban area or countryside);

- the number of people in the family. (Ubóstwo ekonomiczne $w$ Polsce $w$ 2014, 2015: 7).

The at-risk-of-poverty rate is the share of people whose total household income (after social transfers, tax and other deductions) that is available for spending or saving is below the at-risk-of-poverty threshold, which is set at $60 \%$ of the national median equivalised disposable income after social transfers. This indicator measure low income in comparison to other residents in that country (Özdemir and Ward, 2010: 3). There are also opinion that at-risk-of-poverty rate is a measure of income inequalities rather than a direct measure of poverty. In particular other elements such as the available wealth could have a determining influence on the living standards of a given household (income poor vs. wealth). (The measurement of poverty..., 2013: 5).

At-risk-of-poverty threshold in each European Union country is different and depends on the equivalised income. The threshold depends on the income distribution in a country for a given year and varies with the composition of a household. It is therefore important to note that the at-risk-of-poverty rate is a relative measure of poverty and that the threshold varies greatly between Member States. It also varies over time as it follows the evolution of the national median disposable income: in a number of Member States the threshold has fallen over the period 2008-2014 (Greece, Cyprus) or stayed nearly stable (Spain, Italy and Portugal) due to the economic crisis. (The risk of poverty..., 2015: 5). 


\section{Methodology - Method(s) of the analysis}

In this research method of the data analysis was used. Data was taken from the Eurostat database European Union-Statistics on Income and Living Conditions (EU-SILC) data. The Eurostat methodology was used in case of analysis of chosen factors. The research period was 2006-2014. The methodology was applied to four European Union countries: Czech Republic, Hungry, Poland and Slovakia.

Differences in the level of poverty depends on the large number of factors. In this article the author has chosen four of them: the territorial location, the age, the size of the town, the most frequent activity status.

In this research region means NUTS 2. For the determinant age the Eurostat methodology is taking into consideration 4 categories: less than 16 years, from 16 to 24 years, from 25 to 54 years, 55 years or over. The next analysed indicator determining the level of poverty in each analysed country is degree of urbanisation. In this case the Eurostat methodology is taking into consideration 3 categories: cities, towns and suburbs and rural areas. The last determinant of poverty or social exclusion is the most frequent activity status. The Eurostat methodology is taking into consideration 4 categories: employed persons, employees, employed persons except employees and not employed persons.

The first element after the data selection was analysis of the level of the Gini coefficient in the four chosen EU countries in years 2006-2014. Applying the indicator people-at-risk-of poverty or social exclusion was a further step of research. This indicator was compared by regions, age, degree of urbanisation and most frequent activity status. All comparisons were described in tables and on graphs.

\section{Data and empirical analysis}

Empirical analysis used method of the data analysis and was based on the statistical data source The European Union Statistics on Income and Living Conditions (EUSILC) for four countries: the Czech Republic, Hungary, Poland and Slovakia. The Gini coefficient and a people at-risk-of-poverty or social exclusion indexes were used for this analysis. Assumption is that differences in the level of poverty depends on the following determinants: the age, the territorial location, the size of the town and the most frequent activity status.

Analysis of the level of the Gini coefficient in European Union countries indicates that this rate fluctuates around $30 \%$. The biggest declines occurred in the new EU member states. In 2006, this value was 33\%. Then within 9 years, it dropped to $31.1 \%$, which constituted little less than the indicator for the "old" European Union countries. 
Anna Iwacewicz-Ortowska $\bullet$ Diversity of poverty in the chosen European Union countries...

Table 1: Gini coefficient of equivalised disposable income for years 2006-2014

- in percent $(\%)$

\begin{tabular}{|l|r|r|r|r|r|r|r|r|r|}
\hline & 2006 & 2007 & 2008 & 2009 & 2010 & 2011 & 2012 & 2013 & 2014 \\
\hline EU (27 countries) & 30.3 & 30.6 & 31.0 & 30.6 & 30.5 & 30.8 & 30.4 & 30.5 & 30.9 \\
\hline EU (15 countries) & 29.6 & 30.3 & 30.9 & 30.5 & 30.6 & 30.9 & 30.5 & 30.5 & 30.9 \\
\hline $\begin{array}{l}\text { New member states } \\
\text { (12 countries) }\end{array}$ & 33.0 & 31.8 & 31.3 & 30.7 & 30.2 & 30.5 & 30.3 & 30.6 & 31.1 \\
\hline Czech Republic & 25.3 & 25.3 & 24.7 & 25.1 & 24.9 & 25.2 & 24.9 & 24.6 & 25.1 \\
\hline Hungary & 33.3 & 25.6 & 25.2 & 24.7 & 24.1 & 26.9 & 26.9 & 28.3 & 27.9 \\
\hline Poland & 33.3 & 32.2 & 32.0 & 31.4 & 31.1 & 31.1 & 30.9 & 30.7 & 30.8 \\
\hline Slovakia & 28.1 & 24.5 & 23.7 & 24.8 & 25.9 & 25.7 & 25.3 & 24.2 & 26.1 \\
\hline
\end{tabular}

Source: SILC Eurostat database http://epp.eurostat.ec.europa.eu/tgm/table.do?tab=table\&plugin=1\& language $=$ en $\&$ pcode $=$ tessi 190

In 2006, the smallest income diversity was in Czech Republic (25.3\%) and Slovakia (28.1\%). In these countries the Gini coefficient was much lower than in case of the European Union countries, especially the new member states (12 countries) for which he amounted $33 \%$. In the case of Hungary and Poland the Gini coefficient in 2006 amounted to $33.3 \%$, that means it was higher than the average for the new member states. In case of all four analysed countries the Gini coefficient decreased. The greatest decrease took place in case of Hungary and in the end the Gini coefficient in this country in 2014 amounted to the $27.9 \%$. The most disadvantageous situation took place in case of Poland. In 2006 the Gini coefficient amounted to $33.3 \%$ and was the highest in the all European Union. Higher rates in 2006 were characteristic of only following countries: Latvia (38.9\%); Portugal (37.7\%); Lithuania (35\%) and Greece (34.3\%). So Poland and Hungary were in 2006 in the group of the European Union states with the largest income diversity (Table 1).

Apart from the Gini coefficient the next indicator used during analysis of the poverty level is at risk of poverty or social exclusion index.

The risk of poverty, defined as having disposable income of less than $60 \%$ of the national median, is one of the main indicators used in the European Union to identify and monitor social exclusion. The persistent risk of poverty is defined, in the set of indicators used in the EU to monitor social inclusion, as 'having an equivalised disposable income below the at-risk-of-poverty threshold in the current year and in at least two of the preceding three years', where 'current' in practice means the last year for which income data are available and the at-risk-of-poverty threshold is usually taken, as indicated above, as $60 \%$ of the national median. 
The Czech Republic has the highest increased in the threshold of relative measure of poverty in the last nine years. From 2006 the threshold increased there by 1692 Euro.

The lowest at-risk-of-poverty threshold was in Hungry. In 2014 this value didn't exceed 2738 Euro per year. This country has also the lowest change in the threshold which held only 428 Euro per nine years.

Graph 1: At-risk-of-poverty threshold (60\% of median equivalised income)

- in Euro per year

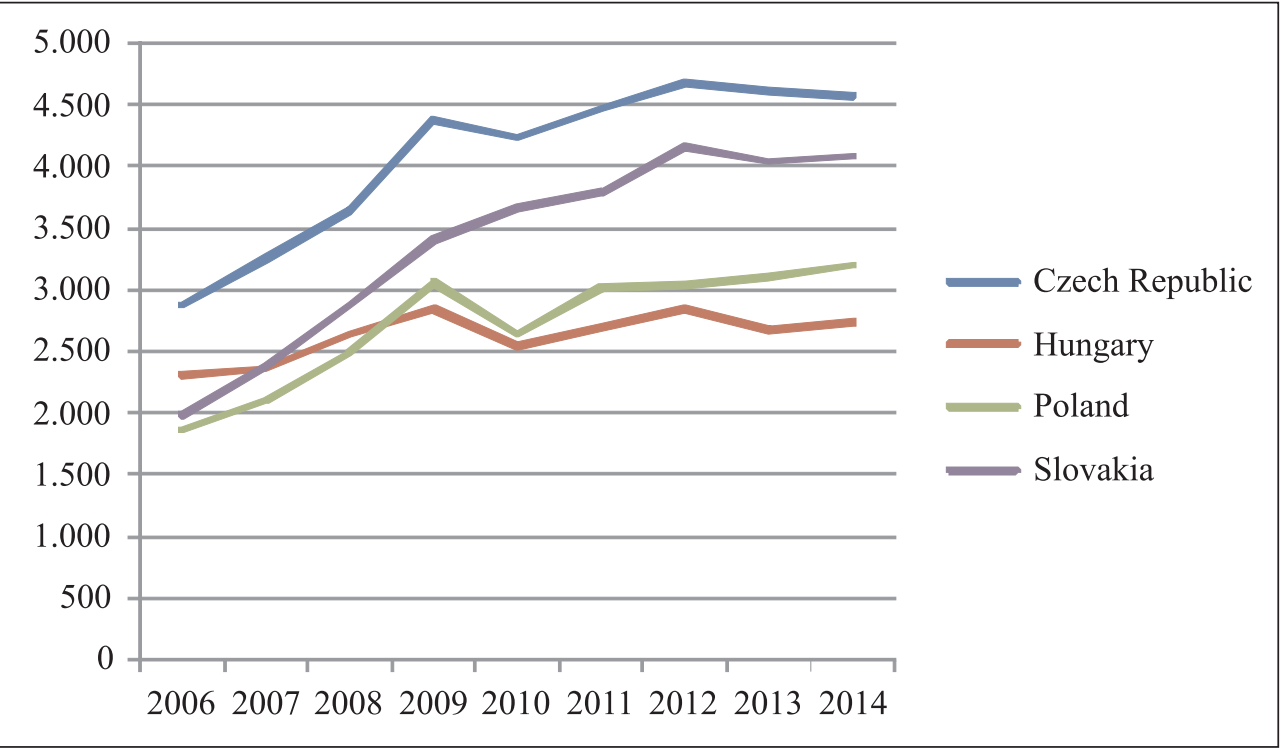

Source: Author's research on the basis of Eurostat dataset (EU SILC)

In 2013, more than a third of the population was at-risk-of-poverty or social exclusion in five Member States: Bulgaria (48.0\%), Romania (40.4\%), Greece (35.7\%), Latvia (35.1\%) and Hungary (33.5\%). On the contrary, the lowest shares of persons being at-risk-of-poverty or social exclusion were recorded in the Czech Republic (14.6\%), the Netherlands (15.9\%), Finland (16.0\%) and Sweden (16.4\%). Among Member States for which data are available, the at-risk-of-poverty or social exclusion rate has increased from 2008 to 2013 in most of the Member States, the only decreases being recorded in Poland (from $30.5 \%$ in 2008 to $25.8 \%$ in 2013), Romania (from $44.2 \%$ to $40.4 \%$ ), Austria (from $20.6 \%$ to $18.8 \%$ ), Finland (from $17.4 \%$ to $16.0 \%$ ), Slovakia (from $20.6 \%$ to $19.8 \%$ ), the Czech Republic (from $15.3 \%$ to $14.6 \%$ ) and France (from $18.5 \%$ to $18.1 \%$ ), while the share remained stable in Belgium. (More than 120 million..., 2014: 2). 
Graph 2: People at-risk-of-poverty or social exclusion in Czech Republic, Hungry, Poland and Slovakia in 2011-2014

- in percent $(\%)$

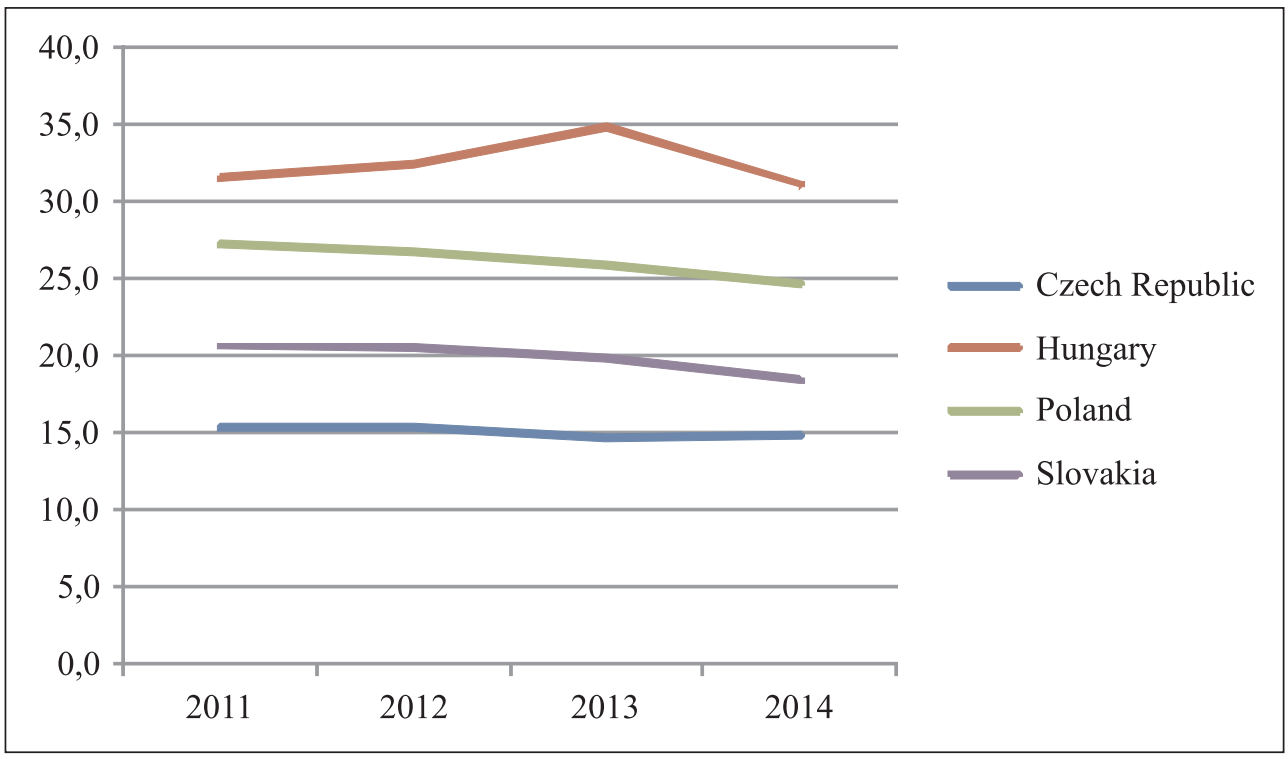

Source: Author's research on the basis of Eurostat dataset (EU SILC)

The indicator people-at-risk-of poverty or social exclusion by NUTS 2 regions in Czech Republic, Hungry, Poland and Slovakia in 2011-2014 (in percentage) is presenting in the table number 2. 
Table 2: People-at-risk-of poverty or social exclusion by NUTS 2 regions in Czech Republic, Hungry, Poland and Slovakia in 2011-2014

- in percent $(\%)$

\begin{tabular}{|c|c|c|c|c|}
\hline Country/Regions & 2011 & 2012 & 2013 & 2014 \\
\hline Czech Republic & 15.3 & 15.4 & 14.6 & 14.8 \\
\hline Praha & 9.1 & 12.5 & 10.2 & 10.2 \\
\hline Strední Cechy & 9.6 & 12.3 & 9.9 & 9.8 \\
\hline Jihozápad & 14.6 & 12.4 & 11.5 & 12.5 \\
\hline Severozápad & 24.6 & 23.7 & 25.8 & 21.9 \\
\hline Severovýchod & 13.8 & 13.2 & 13.8 & 14.0 \\
\hline Jihovýchod & 14.2 & 13.7 & 11.1 & 12.8 \\
\hline Strední Morava & 16.4 & 16.0 & 14.7 & 17.0 \\
\hline Moravskoslezsko & 22.0 & 20.9 & 22.9 & 22.5 \\
\hline Hungary & 31.5 & 32.4 & 34.8 & 31.1 \\
\hline Közép-Magyarország & 26.0 & 28.4 & 32.4 & 29.3 \\
\hline Dunántúl & 28.6 & 28.2 & 29.3 & 26.9 \\
\hline Alföld és Észak & 37.7 & 38.7 & 40.7 & 35.8 \\
\hline Poland & 27.2 & 26.7 & 25.8 & 24.7 \\
\hline Region Centralny & $*$ & 23.6 & 23.6 & 22.6 \\
\hline Region Poludniowy & * & 24.5 & 24.7 & 21.7 \\
\hline Region Wschodni & $*$ & 33.4 & 30.6 & 29.1 \\
\hline Region Pólnocno-Zachodni & $*$ & 27.1 & 24.6 & 24.0 \\
\hline Region Poludniowo-Zachodni & * & 26.6 & 25.2 & 24.1 \\
\hline Region Pólnocny & * & 25.8 & 26.4 & 27.5 \\
\hline Slovakia & 20.6 & 20.5 & 19.8 & 18.4 \\
\hline Bratislavský kraj & 17.1 & 16.9 & 19.6 & 16.5 \\
\hline Západné Slovensko & 18.1 & 18.7 & 17.7 & 15.4 \\
\hline Stredné Slovensko & 20.9 & 22.1 & 20.0 & 20.2 \\
\hline Východné Slovensko & 24.6 & 22.7 & 21.9 & 21.0 \\
\hline
\end{tabular}

Note: * not available data.

Source: Author's research on the basis of Eurostat dataset (EU SILC)

Differences in the level of poverty depends on the large number of factors. In this article the author has chosen four of them: the above described territorial location, the age, the size of the town, the most frequent activity status.

The next analysed group of factors is an age. The Eurostat methodology is taking into consideration 4 categories: less than 16 years, from 16 to 24 years, from 25 to 54 years, 55 years or over. Percentage detailed data of the indicator people-at-risk-of 
Anna Iwacewicz-Ortowska $\bullet$ Diversity of poverty in the chosen European Union countries...

poverty or social exclusion by age for four analysed countries in years 2006-2014 is presenting the table number 3 .

Table 3: People-at-risk-of poverty or social exclusion by age in years 2006-2014

- in percent $(\%)$

\begin{tabular}{|l|c|c|c|c|c|c|c|c|c|c|}
\hline \multicolumn{1}{|c|}{ GEO/TIME } & 2006 & 2007 & 2008 & 2009 & 2010 & 2011 & 2012 & 2013 & 2014 \\
\hline \multicolumn{10}{|c|}{ Less than 16 years } \\
\hline Czech Republic & 22.4 & 21.2 & 18.0 & 16.9 & 17.6 & 19.7 & 18.7 & 16.4 & 20.4 \\
\hline Hungary & 37.8 & 33.8 & 32.0 & 36.9 & 39.4 & 40.3 & 40.4 & 44.6 & 40.8 \\
\hline Poland & 40.9 & 35.5 & 32.0 & 30.2 & 30.1 & 29.2 & 28.6 & 29.4 & 27.9 \\
\hline Slovakia & 29.1 & 23.9 & 22.4 & 21.4 & 24.0 & 23.9 & 25.5 & 23.9 & 21.8 \\
\hline \multicolumn{8}{|c|}{ From 16 to 24 years } \\
\hline Czech Republic & 20.2 & 19.3 & 18.7 & 17.4 & 17.8 & 20.0 & 19.7 & 19.1 & 17.3 \\
\hline Hungary & 34.8 & 35.1 & 35.9 & 36.8 & 36.7 & 38.3 & 39.3 & 42.5 & 38.4 \\
\hline Poland & 45.7 & 39.8 & 34.7 & 30.8 & 31.0 & 30.1 & 31.5 & 31.6 & 31.3 \\
\hline Slovakia & 28.1 & 23.3 & 23.0 & 22.0 & 23.5 & 23.6 & 22.9 & 24.1 & 21.1 \\
\hline \multicolumn{8}{|c|}{ From 25 to 54 years } \\
\hline Czech Republic & 16.9 & 14.2 & 14.0 & 12.2 & 13.1 & 14.1 & 14.3 & 14.1 & 14.1 \\
\hline Hungary & 30.1 & 28.0 & 26.9 & 29.0 & 29.7 & 30.9 & 31.9 & 34.5 & 30.3 \\
\hline Poland & 37.7 & 32.6 & 28.1 & 25.0 & 25.5 & 25.2 & 24.7 & 24.3 & 23.6 \\
\hline Slovakia & 24.9 & 18.5 & 17.5 & 17.5 & 19.1 & 19.6 & 19.0 & 18.6 & 17.6 \\
\hline \multicolumn{8}{|c|}{55 years or over } \\
\hline Czech Republic & 15.9 & 14.0 & 14.6 & 14.0 & 12.9 & 13,4 & 13.7 & 13.3 & 12.8 \\
\hline Hungary & 28.1 & 26.2 & 23.9 & 23.2 & 22.6 & 25,6 & 26.4 & 28.4 & 24.7 \\
\hline Poland & 37.8 & 32.9 & 31.3 & 29.5 & 28.4 & 28,1 & 26.8 & 24.0 & 22.3 \\
\hline Slovakia & 26.9 & 22.9 & 22.5 & 19.8 & 19.2 & 18,1 & 18.8 & 16.2 & 15.8 \\
\hline
\end{tabular}

Source: Author's research on the basis of Eurostat dataset (EU SILC)

In this case the lowest poverty level in the each of age groups includes two countries: the Czech Republic and Slovakia. Age group, with the lowest poverty level is 55 years or over. It is connected with the situation, that persons in this age are usually receiving pension benefits, so are getting the fixed monthly income.

In Poland and Hungry situation in the group 55 years or over is worst than in Czech Republic and Slovakia however in these cases the lowest poverty level is regarding this age group. Situation which positive distinguishes Czech Republic is the third pension pillar. Thanks to to the third pillar about the half of Czech retirement pensions is arising in part from savings put aside by future seniors. It is favourably taxed and isn't bringing such a risk with himself, as remaining pillars. 
Graph 3: People-at-risk-of poverty or social exclusion by age in 2014

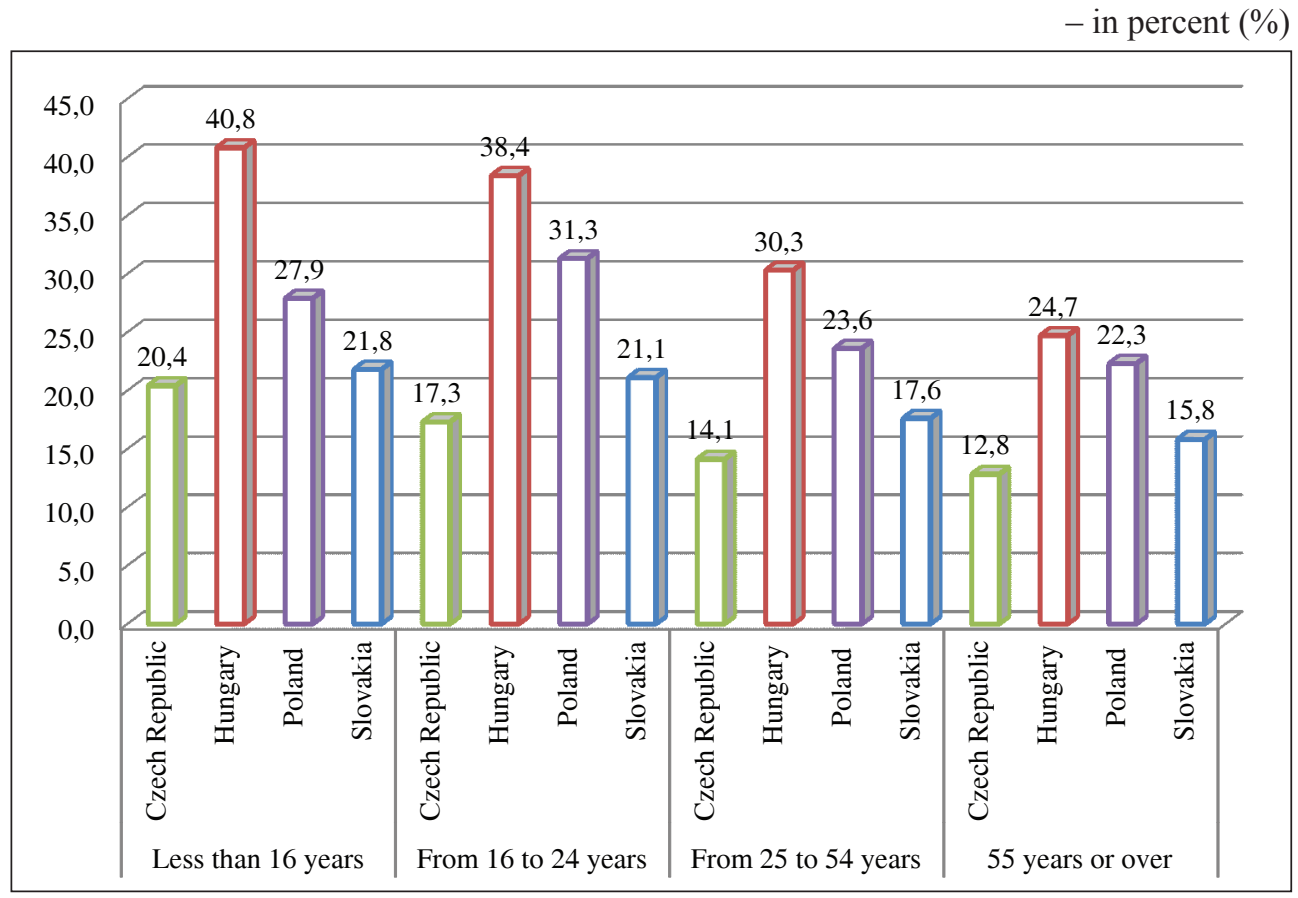

Source: Author's research on the basis of Eurostat dataset (EU SILC)

The next analysed indicator determining the level of poverty in each analysed country is degree of urbanisation.

The Eurostat methodology is taking into consideration 3 categories: cities, towns and suburbs and rural areas. Percentage detailed data of the indicator people at risk of poverty or social exclusion by degree of urbanisation for four analysed countries are presenting in the table number 4. 
Table 4: People-at-risk-of poverty or social exclusion by degree of urbanisation in years 2006-2014

- in percent $(\%)$

\begin{tabular}{|l|c|c|c|c|c|c|c|c|c|}
\hline \multicolumn{1}{|c|}{ GEO/TIME } & 2006 & 2007 & 2008 & 2009 & 2010 & 2011 & 2012 & 2013 & 2014 \\
\hline \multicolumn{8}{|c|}{ Cities } \\
\hline Czech Republic & 18.3 & 14.9 & 15.3 & 13.0 & 12.5 & 14.0 & 14.0 & 13.7 & 13.9 \\
\hline Hungary & 23.1 & 23.7 & 23.5 & 23.1 & 22.1 & 25.3 & 25.8 & 29.1 & 23.7 \\
\hline Poland & 32.3 & 28.0 & 23.5 & 21.1 & 21.1 & 21.2 & 20.4 & 19.8 & 17.8 \\
\hline Slovakia & 23.9 & 17.5 & 17.3 & 14.2 & 15.9 & 15.8 & 14.0 & 17.6 & 15.0 \\
\hline \multicolumn{8}{|c|}{ Towns and suburbs } \\
\hline Czech Republic & 19.8 & 17.3 & 16.9 & 15.4 & 14.3 & 14.9 & 16.7 & 14.8 & 15.4 \\
\hline Hungary & 31.3 & 27.7 & 27.6 & 30.9 & 30.4 & 29.9 & 32.0 & 33.6 & 31.2 \\
\hline Poland & 42.3 & 37.2 & 32.3 & 27.9 & 26.8 & 26.6 & 24.6 & 22.4 & 22.8 \\
\hline Slovakia & 23.6 & 19.6 & 18.3 & 19.3 & 19.1 & 20.2 & 19.5 & 18.7 & 17.8 \\
\hline \multicolumn{10}{|c|}{ Rural areas } \\
\hline Czech Republic & 16.8 & 15.8 & 14.1 & 14.1 & 16.1 & 16.7 & 15.3 & 15.2 & 15.2 \\
\hline Hungary & 37.3 & 33.8 & 31.6 & 33.3 & 34.7 & 36.3 & 37.9 & 40.4 & 36.5 \\
\hline Poland & 45.1 & 39.0 & 36.1 & 33.6 & 33.9 & 32.7 & 33.2 & 32.5 & 31.2 \\
\hline Slovakia & 30.7 & 25.3 & 24.5 & 23.5 & 24.8 & 23.8 & 24.8 & 21.5 & 20.8 \\
\hline
\end{tabular}

Source: Author's research on the basis of Eurostat dataset (EU SILC)

The indicator people-at-risk-of poverty or social exclusion diminished in the Czech Republic, Slovakia and Poland in years 2006-2014. In case of this last country the fall in the level of poverty in the analysed period was the highest. Peculiarly the high level of poverty appeared in 2006 on rural areas in Poland (45.1\% of the whole of population). In 2014 it diminished to the level of $31.2 \%$. 
Graph 4: People-at-risk-of poverty or social exclusion by degree of urbanisation in 2014

- in percent $(\%)$

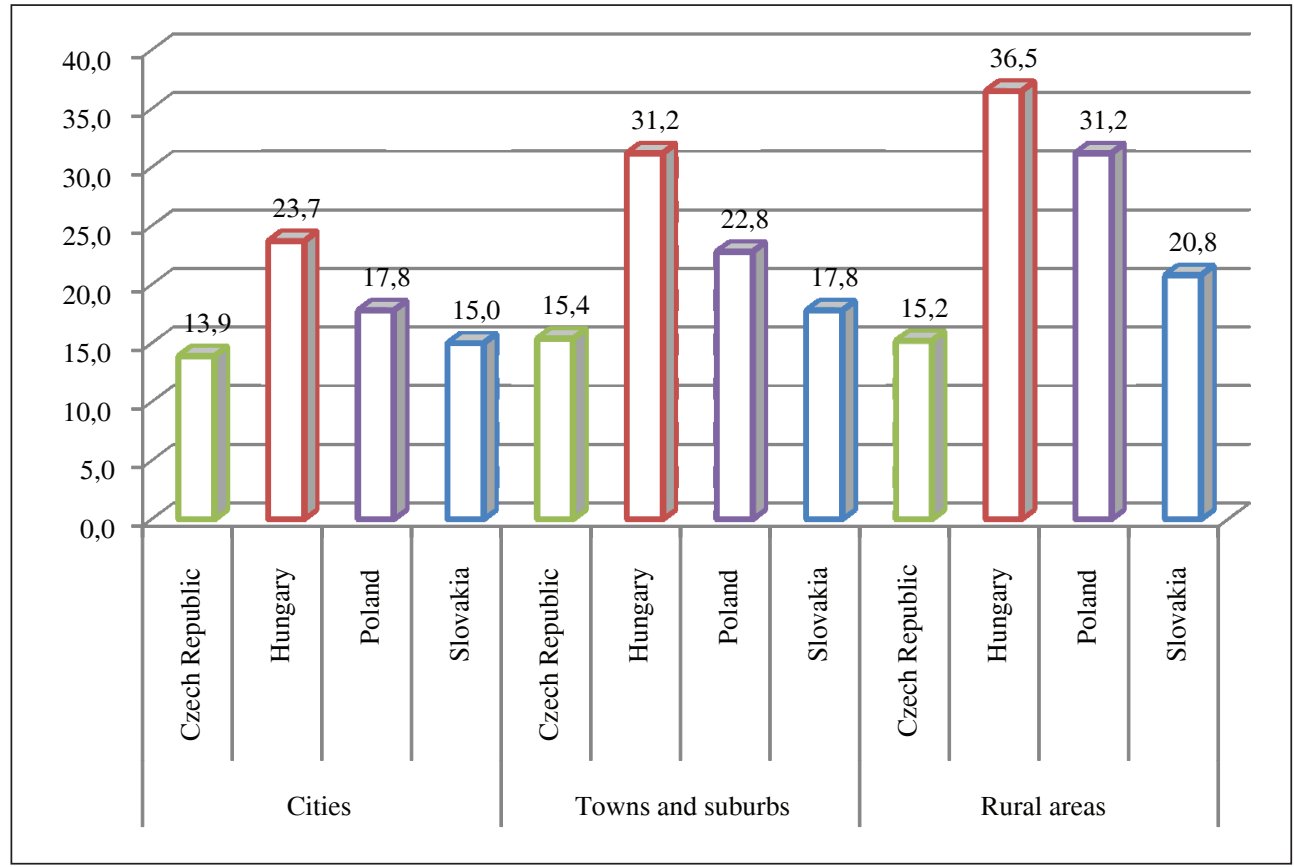

Source: Author's research on the basis of Eurostat dataset (EU SILC)

The last determinant of poverty or social exclusion is the most frequent activity status. The Eurostat methodology is taking into consideration 4 categories: employed persons, employees, employed persons except employees and not employed persons.

Percentage detailed data of the indicator people-at-risk-of poverty or social exclusion by most frequent activity status for four analysed countries in years 20062014 are presenting in the table number 5. 
Table 5: People-at-risk-of poverty or social exclusion by most frequent activity status in years 2006-2014

- in percent (\%)

\begin{tabular}{|c|c|c|c|c|c|c|c|c|c|}
\hline GEO/TIME & 2006 & 2007 & 2008 & 2009 & 2010 & 2011 & 2012 & 2013 & 2014 \\
\hline \multicolumn{10}{|c|}{ Employed persons } \\
\hline Czech Republic & 8.1 & 6.5 & 7.0 & 6.4 & 6.7 & 7.3 & 7.6 & 7.4 & 6.6 \\
\hline Hungary & 18.8 & 18.0 & 16.8 & 19.2 & 18.7 & 19.5 & 20.4 & 23.6 & 19.9 \\
\hline Poland & 27.1 & 23.2 & 20.6 & 17.9 & 17.8 & 17.3 & 17.0 & 16.4 & 15.0 \\
\hline Slovakia & 18.3 & 12.1 & 12.4 & 11.3 & 11.1 & 11.3 & 11.0 & 10.5 & 9.7 \\
\hline \multicolumn{10}{|c|}{ Employees } \\
\hline Czech Republic & $*$ & * & $*$ & 6.3 & 6.0 & 6.8 & 6.8 & 6.7 & 6.1 \\
\hline Hungary & * & * & * & 20.1 & 19.8 & 20.5 & 21.7 & 25.2 & 20.9 \\
\hline Poland & $*$ & * & * & 14.8 & 14.7 & 14.2 & 13.8 & 13.4 & 12.1 \\
\hline Slovakia & $*$ & $*$ & $*$ & 10.4 & 9.4 & 9.3 & 9.5 & 8.6 & 8.6 \\
\hline \multicolumn{10}{|c|}{ Employed persons except employees } \\
\hline Czech Republic & $*$ & $*$ & $*$ & 6.5 & 10.2 & 9.5 & 10.9 & 10.5 & 8.8 \\
\hline Hungary & * & * & * & 12.8 & 10.9 & 12.3 & 10.9 & 11.0 & 11.9 \\
\hline Poland & * & * & * & 30.2 & 29.2 & 29.1 & 29.6 & 28.5 & 26.3 \\
\hline Slovakia & $*$ & * & $*$ & 19.8 & 25.0 & 27.5 & 19.4 & 20.5 & 15.4 \\
\hline \multicolumn{10}{|c|}{ Not employed persons } \\
\hline Czech Republic & 27.4 & 23.8 & 23.9 & 21.9 & 21.2 & 22.3 & 22.7 & 22.2 & 22.0 \\
\hline Hungary & 39.8 & 37.7 & 36.3 & 35.3 & 35.4 & 37.7 & 39.0 & 40.4 & 36.8 \\
\hline Poland & 49.6 & 43.6 & 40.0 & 37.8 & 37.1 & 36.6 & 36.0 & 33.4 & 32.7 \\
\hline Slovakia & 34.5 & 30.3 & 29.2 & 28.0 & 29.2 & 28.6 & 28.2 & 26.7 & 26.6 \\
\hline
\end{tabular}

Note: * not available data.

Source: Author's research on the basis of Eurostat dataset (EU SILC)

Amongst analysed countries the level of unemployment was the highest on Slovakia, where in 2014 amounted to $13.2 \%$. Average unemployment rate for the all European Union countries in the corresponding period is a $10.2 \%$. In three remaining analysed countries the unemployment rate was lower than the average EU and amounted appropriately in Poland 9.0\%, in Hungary 7.7\% whereas in the Czech Republic only $6.1 \%$. In the group of not employed persons the highest fall in the level of poverty took place in Poland, where in 2006-2014 years indicator people-at-risk-of poverty or social exclusion diminished about 16.9 pp. For comparison in Hungary this inheritance amounted to $3 \mathrm{pp}$. 
Graph 5:People-at-risk-of poverty or social exclusion by most frequent activity status in 2014

- in percent $(\%)$

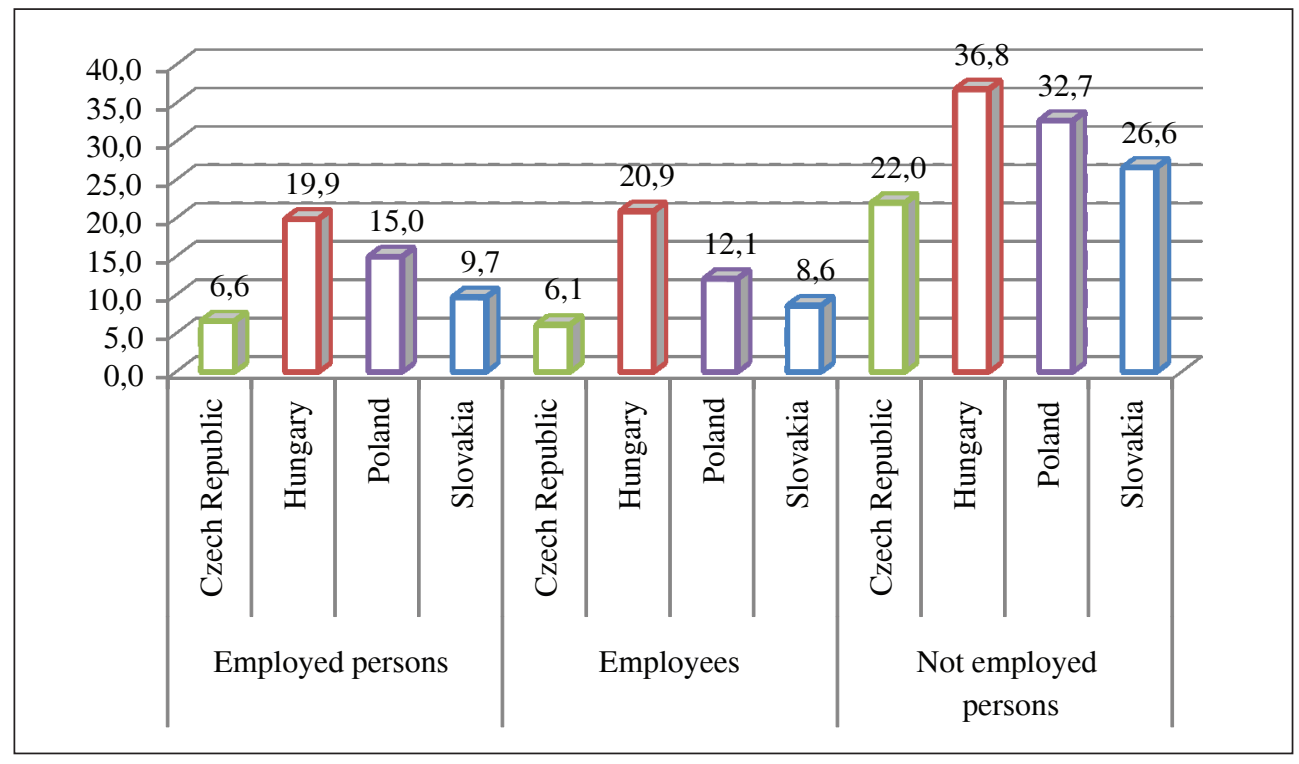

Source: Author's research on the basis of Eurostat dataset (EU SILC)

People-at-risk-of poverty or social exclusion by most frequent activity status shows that group of people most threatened with the poverty are not employed persons. In each of analysed countries this rate exceeds the $20 \%$. The highest was in Hungary, where was amount to $36.8 \%$.

Similarly as well as in the other cases most favourably was Czech Republic. The index people-at-risk-of poverty or social exclusion for employed persons was there $6.6 \%$ and for employees was $6.1 \%$. For Hungry in the same period and for the same group of people was appropriately $19.9 \%$ and $20.9 \%$. The difference was considerable.

\section{Results and discussion}

The Gini coeficient of equivalised disposable income for years 2006-2014 shows that during the nine years the situation has changed. In case of the Czech Republic and Slovakia this change was a little. The Gini coefficient in these countries declined but only a little. The indicator was despite everything relatively low. In 2014 in case of the Czech Republic amounted to $25.1 \%$ whereas in case of Slovakia amounted to $26.1 \%$. Appropriately in case of Hungary in 2014 the Gini coefficient 
amounted to the $27.1 \%$, whereas was the highest in case of Poland $-30.8 \%$. One should emphasize that in the analysed period the situation of many European Union countries changed diametrically. The Gini coefficient of 9 analysed years increased considerably approaching or crossing the threshold of the $35 \%$ in the following countries: Bulgaria (35.4\%), Estonia (35.6\%), Greece, (34.5\%), Spain (34.7\%), Cyprus (34.8\%), Latvia (35.5\%), Lithuania (35.0\%), Portugal (34.5\%) and Romania (34.7\%). Spain, Bulgaria and Cyprus are states which are deserving the particular attention, because growing income disproportion, what the high Gini coefficient is showing, is typical for them. Analysis showed that Norway and Slovenia had the lowest levels of poverty and inequality (as measured by the Gini coefficient) in Europe in 2014, and that Spain and Latvia had the highest one (Di Falco, 2014).

The next indicator used during analysis of the poverty level was at-risk-of-poverty or social exclusion index. Among analysing countries in 2014 the highest one with the amount of 4573 Euro per year was in Czech Republic, than in Slovakia (4 086 Euro per year), Poland (3 202 Euro per year) and Hungry (2 738 Euro per year).

The reduction of the number of persons at-risk-of-poverty or social exclusion in the European Union is one of the key targets of the Europe 2020 strategy. It says that: The number of Europeans living below the national poverty lines should be reduced by $25 \%$, lifting over 20 million people out of poverty (The national poverty line is defined as $60 \%$ of the median disposable income in each Member State) (Communication from the Commission, 2010). In case of the four analysed countries the highest level of the indicator is typical for Hungary. The level of the indicator invariably for a few years exceeds the level of the $30 \%$ in this country. The lowest level of the indicator is appearing in Czech Republic and on Slovakia. Lowest atrisk-of-poverty or social exclusion rate in the all EU is in Czech Republic.

Analysing the level of the people at-risk-of-poverty or social exclusion indicator in individual regions of these four countries one should notice, that regions with the lowest poverty level are Strední Cechy and Praha (in 2014 indicators amounted appropriately to $9.8 \%$ and $10.2 \%$ what is a sensation in the all European Union regions). Apart from these two Czech regions as low indicator as in those regions is only in the region Provincia Autonoma di Bolzano/Bozen in Italy. In 2014 the people at-risk-of-poverty or social exclusion for the region amount to $9.7 \%$. In Czech Republic only two regions get a level of poverty indicator higher than the 20\% (for reminding the average for the entire European Union in 2014 took out about $25 \%$, so $1 / 4$ of the total EU population). Those regions are Moravskoslezsko (indicator on the level of $22.5 \%$ in 2014) and Severozápad (appropriately $21.9 \%$ ). In remaining Czech regions the rate of the level of the people at-risk-of-poverty or social exclusion is fluctuating around a dozen or so what in case of the other EU countries is typical only for the richest regions. The second analysed country, for which the level of indicator at-risk-of-poverty or social exclusion is relatively low is Slovakia. In case of Slovakia this rate declined from the $20.6 \%$ in 2010 to 
the $18.4 \%$ in 2014 lately. Two Slovak regions with the level of the indicator even lower than the average for the entire country are Západné Slovensko (15.4\%) and Bratislavský kraj (16.5\%). Generally Slovak regions are the most sustainable, disproportions between them are only a little and constitute the 5\% scarcely. Regions with the highest level of the indicator people-at-risk-of poverty or social exclusion are Stredné Slovensko (20.2\%) and Východné Slovensko (21.0\%) in the year 2014. Diversity between the poorest and the richest regions is taking less than 5 pp.

Much more diversified country taking into consideration the indicator peopleat-risk-of poverty or social exclusion is Poland. The average indicator level was a $24.7 \%$ in 2014 . A decreasing tendency is a beneficial situation. This rate from 2011 declined about $2.5 \mathrm{pp}$. This is pretty much relating to the other EU countries. The most rich polish regions, with the lowest level of the indicator people-atrisk-of poverty or social exclusion is a Region Poludniowy $(21.7 \%)$ and Region Centralny (22.6\%). The poorest regions with the highest level of the indicator is Region Wschodni (the east part of Poland, close to the board with the Belarus and Ukraine). The level of the indicator was here $29.1 \%$ in 2014.

The last analysed country is Hungary. In case of Hungary average indicator people-at-risk-of poverty or social exclusion in the last four years at first grew and then diminished. Finally his level in 2014 was similar to this one from 2011 and amounted to $31.1 \%$. Region with the highest level of poverty in Hungary is Alföld és Észak (35.8\% in 2014), whereas with the lowest level of poverty is Dunántúl (26.9\%). The highest diversity of the indicator people-at-risk-of poverty or social exclusion between 3 particular regions is typical for Hungary. The difference in 2014 took out as many as $8.9 \mathrm{pp}$.

An increase in the poverty level in the age group less than 16 years is an alarming occurrence. For the example the level of poverty amongst children exceeded the $40 \%$ in Hungary in 2014. The equally high level of poverty appeared in Hungary in the age group from 16 to 24 years, which amounted to $38.4 \%$. Hungary is a country with the highest poverty of children in the entire European Union. The more negative situation is appearing only in Bulgaria, where indicator people-at-risk-of poverty or social exclusion in 2014 amounted to $45.2 \%$ and in Romania, where this indicator amounted to the $50.1 \%$.

One should emphasize that the Czech Republic and Slovakia have relatively the lowest poverty level in the age group from 25 to 54 years, that is in the group of working people. People-at-risk-of poverty or social exclusion in the Czech Republic amounts to $14.1 \%$ while on Slovakia amounts to $17.6 \%$, what comparing to the other European Union countries is a very beneficial situation. The lowest poverty level for this age group appeared only in Iceland (indicator people-at-risk-of poverty or social exclusion amounted there to $11.9 \%$ ) and in Norway (respectively 
$11.8 \%)$. Analyses are showing, that in Hungry in years 2006-2014 level of children poverty (less than 16 years) and young people from 16 to 24 years increased.

Analysing the situation for 2014 one should state, that country with the highest level of poverty is Hungary. Generally in case of each of analysed countries the level of poverty is decreasing along with age. Poland is an exception. The indicator people-at-risk-of poverty or social exclusion is the highest for the age group from 16 it 24 years, it means for the group of students or people after school that try to find their first work.

Undoubtedly, the fall in the level of poverty was an effect of accession of Poland to the European Union and the possibility of receiving EU founds for farmers and land owners. The European Union founds contributed in the meaning way to limit the level of poverty in country areas. However the analogous situation didn't take place in case of Hungary, where level of poverty on towns and suburbs and rural areas in years 2006-2014 practically didn't change. In 2006 the indicator people-atrisk-of poverty or social exclusion for towns and suburbs was $31.3 \%$ and for rural areas $37.3 \%$. In 2014 this indicator amounted appropriately to $31.2 \%$ in 2006 for towns and suburbs (fall only about $0,1 \mathrm{pp}$ ) and $36.5 \%$ for rural areas (fall about $0.8 \mathrm{pp})$. The situation is as interesting because Poland and Hungary acceded to the EU in the same period (accession date was in May 2004) and so business entities, including agricultural farm, could try to get similar sources of structural funding from the European Union. In case of Poland it resulted in the significant reduction of the level of poverty, but in case of Hungary didn't play the substantial role.

In case of inhabitants from all four analysed countries the indicator people-at-riskof poverty or social exclusion is the lowest for the group of people inhabiting cities, whereas the highest for the group of people settling rural areas. One should keep an eye on the Czech Republic, in case of which the relation of the level of poverty and degree of urbanisation isn't appearing. The level of poverty is practically identical for cities, towns and suburbs and rural areas and is hesitating within the limits of 14-15\%. Amongst the all European Union countries with the Czech Republic can only equal Iceland and Norway for which the indicator people-at-risk-of poverty or social exclusion in order to degree of urbanisation are very similar. The last conclusion arising after analysis of the relation of the level of poverty and degree of urbanisation is so that all four analysed countries have in the case of cities lower poverty level than the average for the all European Union. In case of the EU countries the average for cities in 2014 amounted to $24.3 \%$, for towns and suburb $22.3 \%$, whereas for rural areas $27.2 \%$.

Data analysis in the previous part shows that the highest level of poverty is appearing in the group of not employed persons. Persons without employment aren't also getting the regular income. This situation is lowering very much the status of their and their families life. The other interesting conclusion it occurs 
to after analysis of the categories employed persons except employees. The level of poverty in this group of people is particularly high in Poland. However it is surrendering to the slow reduction in 2014 it amounted still to $26.3 \%$ and was over twice higher than in Hungary and three times higher than in Czech Republic. Employed persons except employees receive the much lower remuneration than employees what is adversely affecting the level of poverty. Difference between the remuneration employed persons and employees is particularly high in Poland, what is reflecting in above data. The next interesting observation is arising after analysis of the category employed persons. In case of Hungary the level of poverty in the analysed period 2006-2014 for this category of persons didn't diminish, but even increased slightly. Peculiarly years 2012 and 2013 were disadvantageous. Indicator people-at-risk-of poverty or social exclusion for employed persons in Hungary is practically identical with the indicator people-at-risk-of poverty or social exclusion for not employed persons in Czech Republic. It is showing the large scale of the poverty exactly in Hungary in comparing to the Czech Republic.

\section{Conclusion}

The research proved hypothesis that differences in the level of poverty depends on the following determinants: the age, the territorial location, the size of the town and the most frequent activity status. The poverty in the different level afflicts different social groups. Groups peculiarly exposed to the poverty are above all unemployed persons and their families, young persons, children and inhabitants of towns, suburbs and rural areas. Inhabitants of some regions are threatened with the higher level of poverty in each country. These are mainly outlying districts, far from the capital city of the country. The new facts that come from this research are that analysed four countries that belongs to the Visegrad Group: the Czech Republic, Hungary, Poland and Slovakia although are treated homogeneously are diversified in case of social inequalities. Therefore it seems that the analysis of the poverty level in described countries is an important issue. There is a distinct split in the Visegrad Group into two subgroups. In the first one are the Czech Republic and Slovakia. Typical for this subgroup are the highest increased in the threshold of relative measure of poverty in the analysed period and on the other hand the lowest value of indicator people at-risk-of-poverty or social exclusion. It proves that problem with poverty and inequalities is appropriately noticed and successful eliminated in those two countries. To the second subgroup belongs Hungry and Poland. Typical for this subgroup are the low level of at-risk-of-poverty threshold and the high value of indicator people at-risk-of-poverty or social exclusion. Extremely high value of indicator people at-risk-of-poverty or social exclusion is in Hungry, Poland situation is a little bit better but also not good. In particular the research showed that all four analysed countries have in the case of cities lower poverty level than 
the average for the all European Union. In case of inhabitants for all four analysed countries the indicator people-at-risk-of poverty or social exclusion is the lowest for the group of people inhabiting cities, whereas the highest for the group of people settling rural areas. In Czech Republic the relation of the level of poverty and degree of urbanisation isn't appearing. Limitation of this research was that the poverty level in the analysed countries in 2006-2014 years developed on the similar level to the average poverty level for the all European Union. One should however remember, that the relative poverty threshold in the analysed countries (except the Czech Republic) is almost the lowest from the all European Union countries. Conducting further research for other groups of countries in order to determine the relationship between chosen factors and the level of poverty seems reasonable. The obtained results of the research means that policies to reduce poverty should also concentrate on sustainable long-term growth. Especially in the low-income countries on average, growth has clearly resulted in lower poverty. Development policy should be more concentrated on those aspects because the poverty level is still deepen. Otherwise the market economy has taken priority over social development and environmental concerns in recent years. That also makes problem with poverty increasing. Very important is to promote equality of opportunity in access to education or promoting employment for disadvantaged groups. The usefull could be here redistribution policy with tax policy and transfer system.

\section{References}

Atkinson A. B. (2013) "Reducing income inequality in Europe", IZA Journal of European Labor Studies, Vol. 2, No. 1, pp. 1-11, doi: 10.1186/2193-9012-2-12.

Bellù L. G., Liberati P. (2006) Inequality Analysis. The Gini Index, FAO: Food and Agriculture Organization of the United Nations.

Betti G., et al. (2012) "Subnational indicators of poverty and deprivation in Europe: methodology and applications", Cambridge Journal of Regions, Economy and Society, Vol. 5, No. 1, pp. 129-147, doi: 10.1093/cjres/rsr037.

Bowles S. (2012) The New Economics of Inequality and Redistribution, Cambridge: Cambridge University Press, doi: 10.1017/cbo9781139012980.

Cingano F. (2014) "Trends in Income Inequality and its Impact on Economic Growth" OECD Social, Employment and Migration Working Papers, No. 163, OECD Publishing, Paris, doi: 10.1787/5jxrjncwxv6j-en.

Communication from the Commission (2010) Europe 2020, A strategy for smart, sustainable and inclusive growth, Brussels: European Commission.

Copeland P., Daly M. (2014) "Poverty and social policy in Europe 2020: ungovernable and ungoverned", Policy \& Politics, Vol. 42, No. 3, pp. 351-365, doi: 10.1332/030557312X655503. 
Copus A. (2015) "Regional poverty mapping in Europe - Challenges, advances, benefits and limitations", Local Economy, Vol. 30, No. 7, pp. 742-764, doi: $10.1177 / 0269094215601958$.

Di Falco, E. (2014) "Income inequality: nearly 40 per cent of total income goes to people belonging to highest (fifth) quintile". Eurostat Statistics in Focus, 12, pp. 1-9. Available at: http://ec.europa.eu/eurostat/statistics-explained/index. php/Income_inequality_statistics.

Eurostat (2013) The measurement of poverty and social inclusion in the EU: achievements and further improvements, Eurostat: Working paper 25.

Eurostat (2014) "More than 120 million persons at risk of poverty or social exclusion in 2013", Eurostat News release, Vol. 168, p. 2. Available at: http:// ec.europa.eu/eurostat/documents/2995521/6035076/3-04112014-BP-EN. pdf/62f94e 70-e43a-471f-a466-2e84d1029860 [Accessed: May 9, 2016]

Eurostat (2015) "The risk of poverty or social exclusion affected 1 in 4 persons in the EU in 2014", Eurostat News Release Vol. 181, p. 5. Available at: http:// ec.europa.eu/eurostat/documents/2995521/7034688/3-16102015-CP-EN.pdf [Accessed: April 29, 2016]

Förster M., Pearson M. (2002) "Income Distribution and Poverty in the OECD

Area: Trends and Driving Forces", OECD Economic Studies, No. 1, pp. 7-38, doi: 10.1787/eco_studies-v2002-art2-en.

Główny Urząd Statystyczny (2015) Ubóstwo ekonomiczne w Polsce w 2014 roku, Warszawa: opracowanie sygnalne GUS.

Haase T., Foley R. (2009) Feasibility study for a local poverty index, Dublin: Combat Poverty Agency.

Kołodko G. W. (2008) Wędrujacy świat, Warszawa: Prószyński i spółka.

Leszczyński M. (2009) Bezpieczeństwo społeczne a bezpieczeństwo państwa, Kielce: Wydawnictwo Uniwersytetu Humanistyczno-Przyrodniczego Jana Kochanowskiego.

Leszczyński M. (2011) "Bezpieczeństwo społeczne a współczesne państwo", Zeszyty naukowe akademii marynarki wojennej, No. 2, pp. 123-132.

Milanović B. (2013) "Global Income Inequality in Numbers: in History and Now", Global Policy, Vol. 4, No. 2, pp. 198-208, doi: 10.1596/1813-9450-6259.

Özdemir E., Ward T. (2010) "The persistent risk of poverty", Research note European Commission, No. 7, p. 3.

Stiglitz J. R. (2012) The price of inequality. How today's divided society endangers our future, New York and London: W. W. Norton \& Company.

Stiglitz J. R. (2015) “The origins of inequality, and policies to contain it", National Tax Journal, Vol. 68, No. 2, p. 425-448, doi: 10.17310/ntj.2015.2.09.

Żukrowska K. (2006) Pojęcie bezpieczeństwa i jego ewolucja. In Żukrowska K., Grącik M., ed. Bezpieczeństwo międzynarodowe. Teoria i praktyka, Warszawa: Wydawnictwo SGH. 


\title{
Raznolikost siromaštva u odabranim zemljama Europske unije u razdoblju 2006. - 2014. ${ }^{1}$
}

\author{
Anna Iwacewicz-Orłowska ${ }^{2}$
}

\begin{abstract}
Sažetak
Glavna svrha ovog istraživanja je analizirati promjene razine siromaštva $u$ odabranim zemljama Europske unije u godinama između 2006.-2014. Problem siromaštva i neravnopravnosti poprimio je globalnu dimenziju. Nejednakost dohotka u većini zemalja je znatno viša nego li prije trideset godina. Analiza se temelji na statističkim podacima EU statistike o dohotku i životnim uvjetima (EUSILC) u četiri zemlje: Češkoj, Mađarskoj, Poljskoj i Slovačkoj uz korištenje metode analize podataka. Koeficijent Gini i indeksi naroda s rizikom od siromaštva ili socijalne isključenosti koriste se za ovu analizu. Razlike u razini siromaštva ovise o sljedećim odrednicama: dobi, teritorijalnoj lokaciji, veličini grada i statusu najčešće aktivnosti. Rezultati istraživanja pokazuju da glavne skupine koje su izložene siromaštvu u odabranim zemljama EU su prije svega nezaposlene osobe $i$ njihove obitelji, mlade osobe, djeca $i$ stanovnici gradova, predgrađa i ruralnih područja. Stanovnicima iz okolnih općina, daleko od glavnoga grada prijeti viša razina siromaštva u svakoj od analiziranih zemalja. Rezultati istraživanja dokazuju da siromaštvo različitih razina pogađa različite društvene skupine.
\end{abstract}

Ključne riječi: stopa rizika od siromaštva, Gini koeficijent, nejednakost, siromaštvo

JEL klasifikacija: D63, I31

1 Istraživanje koje je dovelo do ovih rezultata dobilo je potporu u okviru 7. okvirnog programa Europske komisije (FP7/2013-2017) ugovorom no. 312691 InGRID - Inclusive Growth Research Infrastructure Diffusion. Ovaj rad je financiran od strane istraživačkog centra Sveučilišta za financije i menadžment u Białystoku, katedra za ekonomiju.

2 Doktorica ekonomskih znanosti, University of Finance and Management in Biatystok, Poland, ul. Ciepła 40, 15-472 Białystok, Poljska. Znanstveni interes: ekonomija. Tel.: +048 692464884 . E-mail: anna.orlowska@wsfiz.edu.pl. 